\title{
Decorated Women: A Sociological Approach to the Function of Cosmetics in the Books of Esther and Ruth
}

\begin{abstract}
The use of cosmetic oils by the heroines of the books of Esther and Ruth is frequently interpreted as a means to enhance their beauty and allurement. Cosmetic use in the Hebrew Bible is routinely condemned, and yet Esther and Ruth receive no censure for their actions. By utilising a sociological approach to the function of cosmetics and body adornment alongside archaeological and textual evidence from ancient Palestine, in this article I consider the use of cosmetics akin to a speech act, able to communicate the social status and sexual intentions of the wearer to those around them. This perspective provides a new access to understanding the characterisation of Esther and Ruth, showing that their intentions in utilising cosmetic oils fundamentally differs in the two narratives. This has implications for understanding some of the narrative elements within the tales, as well as their reception at the hands of later interpreters.
\end{abstract}

\section{Keywords}

Hebrew Bible; Cosmetics; Body Adornment; Sociological Approach; Ruth; Esther. 


\section{Decorated Women: A Sociological Approach to the Function of Cosmetics in the Books of Esther and Ruth}

The books of Esther and Ruth have frequently been studied in light of each other. As stories named for and featuring female characters from the broad temporal perspective of the Second Temple Period, the similarities between these two tales have often been played up and their heroines compared, thus according to André LaCocque:

Ruth allures Boaz... Esther is wife to a pagan king... The intent of such stories is clear. They want to drive home the idea that women can indeed become God's instruments, even when they use the most controversial resources of their femininity. ${ }^{1}$

According to this interpretation, Esther and Ruth are parallel figures who engage in paralleland controversial-activities that, according to the sub-heading of LaCocque's treatment, should see them labelled as 'subversive figures'. An additional commonality between these two stories that has often been overlooked by commentators is the use of cosmetics by each character. Exploring the sociological function of cosmetics in these narratives provides a new access to understanding each of these figures and the actions which they undertake. There is an increasing body of research that has explored the construction of female gender in the Hebrew Bible and early Jewish literature according to the paradigmatic characterisations of 'Woman Wisdom' and 'Woman Strange', categories most famously developed in the book of Proverbs. ${ }^{2}$ In the books of Esther and Ruth, cosmetics function to blur the boundaries between these categories, allowing a

1 A. Lacocque, The Feminine Unconventional: Four Subversive Figures in Israel's Tradition (Overtures to Biblical Theology; Minneapolis: Fortress, 1990), p. 2.

${ }^{2}$ See e.g. C.V. Camp, Wisdom and the Feminine in the Book of Proverbs (Bible and Literature Series, 11; Sheffield: JSOT, 1985); idem, Wise, Strange and Holy: The Strange Woman and the Making of the Bible (LHBOTS, 320; Sheffield: Sheffield Academic, 2000). 
challenge to the socio-political order. Nevertheless, in each story the transgression of these boundaries has different implications and nuances, providing new impetus to understanding the fundamentally differing characterisation of these two heroines.

In this study, I will explore the use of cosmetics in the Hebrew Bible, and in particular their use in the books of Esther and Ruth. In this context, I understand 'cosmetics' to refer to the application of temporary dyes, powders, perfumes, lotions or oils to the skin for the purposes of decoration and the enhancement of beauty. ${ }^{3}$ The study of cosmetics and their function in the narratives in which they feature have received short shrift in the academic study of the Hebrew Bible and related literature. This scholarly oversight is impacted by the paucity of references to cosmetics in Scripture. Both facts are in large part borne out by the interests of the male scribes who wrote the biblical texts, and the traditionally male scholars who have interpreted them: the gendered implications of Joanne Entwistle's characterisation of the disinterest of the socialsciences in body decoration and adornment as 'unimportant, ephemeral nonsense, unworthy of serious analysis' is surely operative here as well. ${ }^{4}$ Despite this, textual and archaeological data can be utilised alongside sociological models 5 in order to provide insights into the use and

\footnotetext{
3 For this definition see M. DeMello, Encyclopedia of Body Adornment (Westport: Greenwood, 2007), p. 82. The Hebrew Bible is also replete with more permanent examples of body modification such as nose piercing (Gen. 24:22) and ear piercing (Deut. 17:12-17). While tattooing is outlawed in Lev. 19:28, cf. Isa. 44:23, which seems to imply this practice. See S. Jacobs, 'The Body Inscribed: A Priestly Initiative?', in J.E. Taylor (ed.), The Body in Biblical, Christian and Jewish Texts (London: Bloomsbury, 2014), pp. 1-17. The most famous example of permanent body modification in the Bible is of course circumcision (Gen. 17:10-14).

4 J. Entwistle, The Fashioned Body: Fashion, Dress and Modern Social Theory (Cambridge: Polity, 2000), p. 53.
}

5 On the value of a synthesis between textual, archaeological and ethnographic streams of evidence in the interpretation of the Hebrew Bible, see C. Meyers, 'From Household to House of 
function of cosmetics in ancient Palestine - and the importance of such insights for understanding the stories of Esther and Ruth are far from ephemeral.

\section{Archaeological Evidence}

Evidence for the production and application of cosmetics is found throughout the ancient Near East. The ancient Egyptians are perhaps the most famous of the ancient Near Eastern peoples as users of cosmetics, largely due to the iconographic representation in Egyptian art of heavily kohlrimmed eyes for both men and women attested as early as 4000 BCE. Though this had a medical benefit, protecting the wearer from the sun and from insects, this clearly also had a cosmetic function, as evidenced by the highly stylized way in which it came to be applied: for women, the upper lid was coloured black, the lower green, and the space between the upper lid and eyebrow blue or grey, with the function of making the eyes appear larger and more luminous. ${ }^{6}$ By the New Kingdom, women had also begun to apply rouge in the form of red ochre to both lips and cheeks. ${ }^{7}$ (Henna was not known in Egypt until 180 BCE. ${ }^{8}$ ) Perfumed oil provided moisturisation for the body and protection from the sun, as well as deodorization, particularly important in a hot

Yahweh-Women's Religious Culture in Ancient Israel', in A. Lemaire (ed.), Congress Volume: Basel 2001 (VTSup, 92; Leiden: Brill, 2002), pp. 277-303. An extended version of this essay has been published as idem, Households and Holiness: The Religious Culture of Israelite Women (Minneapolis: Fortress, 2005), see esp. pp. 19-26.

${ }^{6}$ See J. Fletcher, 'The Decorated Body in Ancient Egypt: Hairstyles, Cosmetics and Tattoos', in L. Cleland, M. Harlow and L. Lewellyn-Jones (eds.), The Clothed Body in the Ancient World (Oxford: Oxbow Books, 2005), pp. 8-9.

7 Ibid, p. 10.

8 L. Renault, 'Recherches sur le henné antique', JNES 68 (2009), pp. 193-212. 
climate. ${ }^{9}$ Unsurprisingly, then, the archaeological evidence shows that cosmetic containers abounded in all periods of Egyptian history, preserved as grave goods alongside other luxury items.

In Mesopotamia, cosmetic containers at the royal cemetery at Ur already from the third millennium pertain to the popularity of cosmetic preparations, the most popular pigments coloured black and green, though other colours are also in evidence..$^{10}$ Indeed, green and black pigments in cosmetic cases have been found throughout Mesopotamian history, ${ }^{11}$ though it is not always possible to separate the use of cosmetics for the purposes of beautification, medication or ritual. Cosmetic capsules, for example, have been found deposited in temples, ${ }^{12}$ while the application of kohl to the eyes had an antiseptic function. Nevertheless, beautification was clearly also an intention of the application of cosmetics: in the Sumerian myth of Inanna's descent, the goddess applies a kohl to her eyes called “Man, come, come!".13 In the Sumerian song cycle about Inanna and Damuzi (Tammuz), the order in which the goddess applied her cosmetics is given: first she washed herself, anointed herself with oil, put on her royal garb, applied kohl to her eyes,

\footnotetext{
${ }^{9}$ L. Manniche, Sacred Luxuries: Fragrance, Aromatherapy, and Cosmetics in Ancient Egypt (Ithaca: Cornell University Press, 1999), p. 144.

10 See M. Bimson, 'Cosmetic Pigments from the "Royal Cemetery" at Ur', Iraq 42 (1980), pp. 75 -
} 77.

11 P.R.S. Moorley, Ancient Mesopotamian Materials and Industries: The Archaeological Evidence (Oxford: Clarendon, 1994), pp. 138-139.

${ }^{12}$ For example, in the temple at Tell al-Rimah in the mid second millennium BCE. See T.H. Carter, 'Excavations at Tell al-Rimah: Preliminary Report', BASOR 178 (1965), pp. 50-51.

${ }^{13}$ S.N. Kramer, 'Inanna's Descent to the Netherworld: Continued and Revised', JCS 5 (1951), pp. 1-17. Inanna is also associated with the application of kohl in a hymn from the Ur III period, see Y. Klein, Three Šulgi Hymns: Sumerian Royal Hymns Glorifying King Šulgi of Ur (Ramat Gan: BarIlan University Press, 1981), p. 137. 
tied up her hair, put a golden ring upon her finger, and fastened a string of lapis lazuli beads around her neck. ${ }^{14}$ According to Marten Stol, we have no reason not to think that the women of the ancient Near East undertook a similar routine of daily ablutions and preparation. ${ }^{15}$

The popularity of cosmetics in ancient Palestine is attested by the wealth of archaeological material related to beauty and beauty treatments, incorporating numerous tools for the application of cosmetics, as well as storage containers for powders, creams and oils, perfume bottles, and polished mirrors. ${ }^{16}$ Excavations at Ein Gedi on the western shore of the Dead Sea have uncovered a settlement dating between the seventh and sixth centuries BCE, the latter part of the Judaean monarchy. The discovery of multiple pottery vats and lumps of henna at the site suggest the association of the settlement with cosmetic preparation. ${ }^{17}$ Certainly a building of the first century CE, discovered at En Boqeq on the shore of the Dead Sea, is to be identified as a workshop for the production of perfume, ${ }^{18}$ perhaps exploiting the location of the Dead Sea where balsam and palm tress grow in abundance. Indeed, perfume bottles were discovered in large numbers at a burial tomb at Ketef Hinnom in Jerusalem dating from the seventh to sixth centuries BCE. ${ }^{19}$ The high value afforded the contents of these bottles is suggested both by their small size, and the fine

14 Y. Sefati, Love Songs in Sumerian Literature: Critical Edition of the Dumuzi-Inanna Songs (Ramat Gan: Bar-Ilan University Press, 1998), p. 135.

${ }^{15}$ M. Stol, Women in the Ancient Near East (trans. H. and M. Richardson; Berlin: de Gruyter, 2016), pp. 47-48.

${ }^{16}$ For an excellent treatment of this assemblage, focused especially on finds from Hazor and Megiddo, see R. Jacob, Kosmetik im antiken Palästina (AOAT, 389; Münster: Ugarit-Verlag, 2011), pp. 93-276.

17 So M. Dayagi-Mendels, Perfumes and Cosmetics in the Ancient World (Jerusalem: The Israel Museum, 1989), pp. 109-111.

18 Ibid, p. 109.

19 Ibid, p. 127. 
materials used in their production: the ownership of cosmetics was a luxury in ancient Palestine, but nevertheless a luxury which seems to have been fairly widespread throughout the population.

\section{Textual Sources}

Given the extent of the archaeological evidence for cosmetics in ancient Palestine, we might expect to find multiple references to the application of cosmetics in the Hebrew Bible. Yet references are fairly few, save for the use of oil in the purposes of ritual anointment, leading Michal Dayagi-Mendels to (incorrectly) claim that the Bible 'makes no mention of other uses of cosmetics [i.e. for non-ritual purposes] during the First Temple period'. ${ }^{20}$ Yet while the magicoreligious use of oil in ritual settings is certainly an important facet of the application of oil, clearly this could also serve a cosmetic function too, applied in order to enhance the beauty of the wearer. Consequently, the interpreter must pay close attention to the function of the application of oil in any given biblical text. Alongside perfumed oil, the use of eye paint is also borne out by the biblical sources. The general term 'cosmetics' translates the Hebrew word תמרוק (so the NRSV, NASV, NET, and ESV translations of Esth. 2:3, 9, 12; NKJV has 'beauty preparations'; while NIV 'beauty treatments'), the lexeme coming from the verb מרק, 'to polish, burnish, scour' (hence the translation of the KJV, 'things for purification'). 21 'Oil', as noted can have ritual purposes (as well as uses in food, lighting, and medicine, see e.g. Isa. 25:6; Exod. 25:6; Isa. 1:6), however it was also used as a cosmetic to soften the skin (Pss. 92:11; 133:2; Ezek. 16:9; Amos 6:6), and could be used in combination with perfume:שמן רוקח, 'perfumed oil' is found in Song 5:13 and Eccl. 10:1; another type of perfumed oil, שמן תורק, is mentioned in Song 1:3.22 Indeed, there are multiple

\footnotetext{
${ }^{20}$ Ibid, p. 8.

${ }^{21}$ See HALOT, 638a.

${ }^{22}$ The precise meaning of this phrase is disputed: though the Peshitta translates שממן תורק as dmwr', 'oil of myrrh', compounding the problem with the translation the lexeme תורק is often
} 
types of perfume mentioned in the Hebrew Bible, occurring with especial frequency in the Song of Songs, for example בשםם, probably 'balsam', and מר ,myrrh' (Song. 1:13; 4:14; 5:1, 5, etc.). In Song 1:13, myrrh is placed into a sachet and worn between the woman's breasts. Various forms of the root מרקחים . describe perfumed ointments, e.gerfume' in Song 5:13, and שמקן רוקה, 'perfumed oil' in Eccl. 10:1. In Song 1:13-14, Ein Gedi is mentioned as a centre for the production of perfume, corresponding with the archaeological evidence discussed above. Perfumes were clearly expensive, as indicated by 2 Kgs 20:13, where they are stored together with silver and gold. Indeed, spices were among the luxury goods gifted by the Queen of Sheba to King Solomon (1 Kgs 10:2, 10). In the New Testament, we read that costly perfumed oils and ointments were stored in alabaster boxes (Matt. 26:7, 9; Mark 14:3), and a cosmetic container also seems to be referenced in Isa. 3:20. The application of oil was prohibited to women in mourning (2 Sam. 14:2). In 1 Sam. 8:13, female palace servants are associated with the production of personal body products. Carol Meyers has made a case that midwifery provided women in ancient Israel with a specifically female outlet for ritual, medical and technological productions; ${ }^{23}$ correspondingly, given the reference in 1 Sam. 8:13 coupled with the frequency with which the use of fragranced oil is associated with women, ${ }^{24}$ the production of cosmetic items such as oils might also be considered a part of the female technological domain.

analyzed as the hophal form of the verb ריק, 'to be emptied out' (so the reading of the LXX, $\mu$ vipov $\dot{\varepsilon} \kappa \kappa \varepsilon v \omega \theta \dot{\varepsilon} v$, 'perfume poured out'). For a recent discussion of the term see G.A. Rendsburg and I. Young, 'שמן תורק šemen turaq (Song 1:3)', in G.A. Rendsburg and F.E. Greenspahn (eds.), Le-ma'an Ziony (Festschrift Z. Zevit; Eugene: Cascade Books, 2016), pp. 383-396.

${ }^{23}$ C. Meyers, Rediscovering Eve: Ancient Israelite Women in Context (Oxford: OUP, 2012), pp. 171179.

${ }^{24}$ See e.g. Isa. 3:24; Pss. 27:9; 45:8; Song 4:10-11; Esth. 2:12, etc. 
Similarly, and in contrast to the wider ancient Near East, the use of eye paint is also a gendered activity in the Hebrew Bible, associated only with women. In 2 Kgs 9:30 Jezebel lines her eyes with פוך, probably kohl or antimony. One of Job's daughters is named קרן הפוך, KerenHappuch (Job. 42:14), presumably after a receptacle for the storage of eye paint. ${ }^{25}$ The lexeme is used again in Jer. 4:30, here in conjunction with the verb קרע, 'to rip, to tear up', which is semantically equivalent to the verb used for kohl-application in Akkadian, sahālum-D, 'to prick, to pierce'.26 In Ezek. 23:40 the hapax legomenon כחל clearly describes this same process of painting the eyes; the lexeme may be related to the Arabic noun kuhl, Akkadian guhlu, and Aramaic $k h l$, the latter of which is used to translate the references to kohl application in the Targumim of 2 Kgs 9:30 and Jer. 4:30.

With the exception of Job's daughter, whose name perhaps alludes to her beauty (cf. Job 42:15: 'Nowhere in the land could women be found who were as beautiful as Job's daughters'), the biblical references to eye painting are always negative, connected to Queen Jezebel (2 Kgs 9:30) and with prostitution in Jeremiah and Ezekiel (Jer. 4:30; Ezek. 23:40). The use of perfumed oil is more ambiguous, and its virtues are extolled in the Song of Songs. ${ }^{27}$ Nevertheless, numerous references associate women's use of perfumes, oils, eye paints, clothing, and jewellery with prostitution ${ }^{28}$ and moral corruption (Isa. 3:16-24; Jer. 4:30; Ezek. 16:15-18; 23:40-42; Amos 6:6;

25 The name בשטמת, Basemath (Gen. 26:34; 36:3; 1 Kgs 4:11), may be connected with perfume or balsam.

26 On the semantics of the Akkadian lexeme, see N. Wasserman, 'Piercing the Eyes: An Old Babylonian Love Incantation and the Preparation of Kohl', BiOr 72 (2015), pp. 601-612.

${ }^{27}$ See A. Brenner, 'Aromatics and Perfumes in the Song of Songs', JSOT 25 (1983), pp. 75-81.

${ }^{28}$ While secular prostitution per se is not outlawed in the Hebrew Bible, nevertheless it is a morally inferior occupation and is specifically prohibited for the daughters of Israel (e.g. at Lev. 19:29). Prostitution is also frequently linked with adultery, especially in the oft-used metaphor 
Eccl. 7:1), while vanity in general is denounced (Prov. 31:30). These negative associations of cosmetics are taken over into later Jewish literature, ${ }^{29}$ for example in 1 Enoch 8:1-4, where female beautification and ornamentation is associated with instruments of war; both were taught by the angel Azazel to humanity. The text is explicit in its condemnation of cosmetics: 'The whole earth has been ruined by the teaching of the works of Azazel' (10:8). Correspondingly, in the Talmud the utilisation of cosmetics for immoral purposes is decried: wanton women would perfume their shoes in order to arouse young men (Shab. 62b); while prostitutes were particularly associated with the use of eye paint (Shab. 34a) and perfumes (Shem. R. 43:7). Indeed, the demand for perfume was said to be particularly high in the 'Market [street] of the Prostitutes' (Ex. R. 43:7).

The connotations of cosmetics with specifically female moral corruption and prostitution is reminiscent of the characterisation of the immoral woman in the book of Proverbs as 'Woman Strange' (זריה or see e.g. Prov. 2:16-19; 5:3-8, 20; 6:24-26, 19, 32; 7:5-27; 22:14; 23:27-28; $30: 20 ; 31: 3)$. While the meaning of both lexemes in the Hebrew essentially indicates foreignness, the descriptions of this character more often conjure up images of illicit sexual activity rather than an ethnic, legal or social status. ${ }^{30}$ The meaning of 'foreign' in this case is essentially 'otherness', employed to describe a character of 'loose morals, devious charms and deviant religious convictions'. ${ }^{31}$ This negativized every-woman is countered by 'Woman Wisdom' (חכמה;

which depicts Israel as a faithless wife or prostitute who has turned away from God her husband, and frequently employed by Hosea, Jeremiah and Ezekiel.

${ }^{29}$ Cosmetics also feature at key points in the story of Susanna from the Additions to Daniel, and in the book of Judith. It is my intention to treat the function of cosmetics in these two Apocryphal tales in a separate study.

30 So Camp, Wise, Strange and Holy, p. 29: 'real ethnic foreign women and their gods are less a concern than all the metaphoric implications associated with them'.

31 A. Brenner-Idan, The Israelite Woman: Social Role and Literary Type in Biblical Narrative (London: Bloomsbury, 2nd edn, 2015), p. 122. 
see e.g. Job. 28:1-28; Prov. 1:20-33; 3:13-18; 4:1-9; 7:1-5; 8:1-36; 9:1-6; 14:1; Wis. 6:12-11:1; Sir. 1:1-20; 4:11-19; 6:18-37; 14:20-15:10; 24:1-34; 51:13-30; Bar. 3:9-4:4; 2 Esdr. 13:54-55), described as the idealised, faithful wife (esp. Prov. 3:13-18; 4:5-9; 7:4-5; and 9:1-6).

Woman Strange is associated with the application of cosmetics (e.g. at Prov. 7:16-17);32 her beauty is in fact the cause of her sexual sorcery, and is therefore condemned. On the other hand, the sexuality of Woman Wisdom, the ideal wife, is exclusively restricted to marriage. Indeed, in the description of the אשית חיל, the worthy or capable wife, outlined in Prov. 31:10-31, this figure is explicitly contrasted with the woman who is charming but vain in v. 30 . Beauty is associated with temptation toward illicit sexual relations, and hence the heightening of beauty with cosmetic preparations is to be feared. The characterisation of these two figures gives Israelite women a choice of paradigmatic role models, either good (Woman Wisdom, the worthy wife, whose sexuality is controlled) or bad (Woman Strange, a dangerous and immoral seductress). The role of the former acts within the parameters of a male-dominant society, and the latter, by means of her beguiling charm-heightened by the application of cosmetic preparations-uses her sexuality to subvert this society. A woman in control of her sexuality is hence an extremely dangerous figure.

In the midst of this gendered discourse, the conclusion that cosmetics, if not prohibited, were understood ill-favourably by the scribes who authored the Hebrew Bible and early Jewish texts seems obvious. Despite the prevalence of archaeological finds pertaining to the use of cosmetics in ancient Israel, the masculine voices that shaped Scripture commonly associate the use of beautifying preparations with immorality and illicit sexual practices. This has been borne out both by our study of kohl and perfumed oil in the Hebrew Bible and early Jewish literature, and is consistent with the unfavourable depiction of Woman Strange and her deviant sexual

\footnotetext{
32 On the role of perfume in the Woman Strange discourse see G.A. Yee, “'I Have Perfumed My Bed with Myrrh": The Foreign Woman ('išša zārâ) in Proverbs 1-9', in A. Brenner (ed.), A Feminist Companion to Wisdom Literature (Sheffield: Sheffield Academic, 1995), pp. 110-126.
} 
charm, contrasted with her counterpart, the chaste and pure Woman Wisdom. From this perspective it would seem that the ideal Israelite woman would avoid the use of cosmetics. Yet there are two further references to the use of beautifying oil in the Hebrew Bible that are anomalous in this context: both Esther and Ruth utilise oil for cosmetic purposes in the books that bear their names, and both escape criticism - in fact, each character receives praise, not censure, in the course of the narratives. In order to understand the function of their application of cosmetics and hence the reasons behind the lack of censure in these two tales, sociological models provide a vital insight into the meanings encoded by an adorned, cosmetically-enhanced body.

\section{Sociological Discussion}

There is a growing body of scholarship conducted by academics in the social-sciences that is concerned with body adornment, encompassing clothes, cosmetics, and other forms of decoration as an embodied activity embedded within social relations. Drawing on the work of scholars such as Mary Douglas, Marcel Mauss, and Pierre Bordieu, this scholarship has demonstrated that body adornment should be understood as a form of communication and symbol of the social order. ${ }^{33}$ Adornment is the means by which bodies are made social, the 'social skin' which models social

${ }^{33}$ See M. Douglas, Body Symbols (Oxford: Blackwells, 1970); idem, Natural Symbols (New York: Pantheon Books, 1982); M. Mauss, 'Techniques of the Body', Economy and Society 2 (1973), pp. 70-87; and P. Bordieu, 'The Biographical Illusion', Actes de la Recherche en Sciences Sociales 62-3 (1986), pp. 69-72. On the history of the development of a sociological approach to the clothed and adorned body, see J. Craik, The Face of Fashion: Cultural Studies in Fashion (London: Routledge, 1994), pp. 1-17. 
boundaries between an individual actor and other actors. ${ }^{34}$ Our social skin requires attention, whether unconscious or otherwise, to the norms and expectations of these other actors within a particular social setting: 'the social body constrains the way the physical body is perceived'. 35 Body adornment is thus the visible form of our intentions, and the reverse of this, 'the image by which we are read and come to be read by others'. ${ }^{36}$ There are 'right' and 'wrong' ways of being in any given social space - and hence right and wrong ways of appearing, dressing and adorning oneself. Dress is thus an effective means of non-verbal communication, but one which at the same time is controlled and dictated through normative social values. ${ }^{37}$ To transgress these values is to communicate something specific about one's social or sexual status.

An example of this process at play is in the construction of gender. While the connection between certain modes of dress with concepts of 'femininity' or 'masculinity' is essentially arbitrary, ${ }^{38}$ a set of culturally specific associations regulate dress along gendered spectrums. Body adornment can communicate diverse social structures such as status and other negotiations in daily life - and crucially, it can mark out sexual identities. As Joanne Entwistle has shown, body

${ }^{34}$ On the concept of 'social skin' see T.S. Turner, 'The Social Skin', in J. Cherfas and R. Lewin (eds.),
Not Work Alone: A Cross-Cultural View of Activities Superfluous to Survival (London: Temple Smith, 1980), pp. 112-140.

35 Douglas, Natural Symbols, p. 93.

${ }^{36}$ Entwistle, The Fashioned Body, p. 85.

${ }^{37}$ On dress as a form of social control, see L.B. Arthur, 'Dress and the Social Control of the Body', in L.B. Arthur (ed.), Religion, Dress and the Body (Oxford: Berg, 1999), pp. 1-9.

38 On the other hand, clothing and adornment frequently evokes the sexed body, drawing attention to sexual difference between males and females. See J. Craik, “I Must Put On My Face”: Making Up the Body and Marking Out the Feminine', Cultural Studies 3 (1989), pp. 1-24; and R. Russell, 'Why Cosmetics Work', in R.B. Adams et al. (eds.), The Science of Social Vision (Oxford: OUP, 2010), pp. 186-203. 
adornment can be read in order to 'differentiate between the good, gentle woman and her "fallen" sister, the prostitute'. ${ }^{39}$ Certain cosmetic preparations or clothes can be connected to these binary images, articulating sexual continence or availability. Sexual intention is thus heavily coded through dress and adornment. In the modern world, we are frequently confronted with instances in which a woman is held accountable for unwanted male attention based upon the mode of her dress. The perception of failure to heed conventional-often male-expectations in dress has been utilised to blame women for males own lax in behavioural norms: the man has succumbed to sexual temptation because the woman has dressed 'provocatively', whatever that is taken to mean within a particular social setting. In this case, there has been a miscommunication of the bodily symbols of social display, with negative consequences. But the body as an agent in (sexual) communication can also be positively and purposefully utilised, allowing an individual to express sexuality and articulate desire. It can be utilised strategically: Entwistle gives the example of the prostitute, whose dress and demeanour is heavily sexually coded. 40

The story of Tamar and her father-in-law Judah from Genesis 38 is an example of this in action from the biblical world. Widowed twice in quick succession by two brothers, the requirements of the Levirate law (Deut. 25:5-10) necessitate that Tamar marry the third brother, with any subsequent offspring named for his deceased relatives. But Tamar's father-in-law refuses to sanction the marriage and fulfil this legal obligation. Tamar 'covers herself with a veil' in order to disguise herself as a prostitute (v. 14) and Judah accordingly 'thought she was a prostitute, for she had covered her face' (v. 15). The resulting sexual union between the two sees Tamar conceive twin children: her actions, which might at first seem morally questionable, actually enable the Levirate law to be properly upheld. By changing her clothes, Tamar is able to communicate her sexual availability to Judah, though her actual status is a widow and hence her proper role as a non-sexual being. Following the sexual activity, she returns to her widow's garb

\footnotetext{
${ }^{39}$ Entwistle, The Fashioned Body, p. 150.

40 Ibid, p. 207.
} 
(v. 19), and consequently back into her normative role: the narrative is explicit that Judah 'did not know her again' (v. 26). This speaks of the capacity of non-permanent forms of body adornment such as clothes and cosmetics to be employed with intent by the wearer, changed at will in order to allow an individual to adopt and discard multiple sexual identities and personalities.

In the following I will explore the use of cosmetics by Esther and Ruth, remaining sensitive to this understanding of cosmetics as a form of social communication. In this case, I will understand the utilisation of cosmetics by these two figures as the symbolic means by which certain desires and intentions are communicated by the wearers, and read by those around them. In so doing, a new access to both the intention of the narrative and the characterization of the individual figures will be provided. Ultimately it will be shown that this sociological perspective on the role of cosmetics is essential to properly reading and understanding these two biblical books.

\section{The Book of Esther}

The setting of the book of Esther is in the Diaspora, among the Jewish exiles living in Persia. ${ }^{41}$ After his wife Vashti refuses to oblige his request to appear before him and his dinner guests, King Ahasuerus of Persia is in want of a new wife. Esther, hand-picked from the king's harem, is chosen and through the political machinations of herself and her cousin Mordechai across a series of banquets and feasts, is able to thwart the plot of Haman to destroy the Jews of Persia, ultimately resulting in the bloodthirsty destruction of the enemies of the Jews. The crucial turning point in the fortunes of Esther is when Ahasuerus chooses her to be his bride. The virgin girls of the king's

\footnotetext{
${ }^{41}$ Accordingly, the book contains a number of Persian loanwords as well as the characteristic features of Late Biblical Hebrew, appropriate to a composition written in the broad period of the Second Temple. For a recent review of the history of research on the book of Esther, see A. Erickson and A.R. Davis, 'Recent Research on the Megilloth (Song of Songs, Ruth, Lamentations, Ecclesiastes, Esther)', CBR 14 (2016), pp. 298-318.
} 
harem are required to undergo a twelve-month beauty treatment before being presented to the king: six months with oil of myrrh (שמקן המר) and six months with perfumes (בשם) and cosmetics (תמרוק). בואי king, which is often utilised in the Hebrew Bible as a euphemism for sexual activity (e.g. Gen. 16:2; 29:21, 23; 2 Sam. 11:4; 16:21, 22). After her evening in the king's company she does not return to the residence of the virgins, but to a second harem, the house of the concubines (2:14), unless she has found special favour in the eyes of the king. This is the case with Esther, who is crowned as queen following her night with the king. Thus the king apparently couches his choice of queen upon two criteria: the potential bride's beauty, and her ability to please him sexually. In this context the application of cosmetics plays an important role in the enhancement of Esther's beauty and sexuality (oil of myrrh in particular is associated with sexuality in Song 1:13; 5:1-13; Prov. 7:17; and Ps. 45:8). Through cosmetic application, Esther adopts a heavily sexualised persona, and it is this that ultimately ensures her favourable treatment by the Persian king. While Vashti tries to deflect the male gaze and is thus deposed, Esther seeks to attract it, communicating through the application of cosmetics her willingness to conform to the king's expectations (after all, the choice of the term דתת, 'edict', to describe the requirement for the cosmetic treatments

${ }^{42} \mathrm{~W}$. Albright's attempt to explain the unusually lengthy period of beautification according to the archaeological evidence of cosmetic burners, in which an extended period of time was necessary in order to properly impregnate a woman's clothes and skin with perfumed fumes (W. Albright, 'The Lachish Cosmetic Burner and Esther 2:12', in H. Bream et al. [eds.], A Light unto My Path [Festschrift J.M. Myers; Philadelphia: Temple University Press, 1975], pp. 25-32), is too literal a reading: instead the figure can be understood as an instance of the use of exaggerated numbers for comic effect, a frequent occurrence in the book of Esther (so the 127 provinces, a 180-day party, Haman's offer of 10,000 talents of silver, a stake 50 cubits high, and 75,000 enemies dead). See A. Berlin, The JPS Bible Commentary: Esther (Philadelphia: JPS, 2001), p. xxvii. 
indicates the seriousness with which these cosmetic preparations were regarded ${ }^{43}$ ). The lengthy beauty treatment thus affects Esther's change in status from young orphaned girl to desirable woman and potential queen. Indeed, Esther is able to subvert the normative social order through her sexuality: her favour with the king enables her to save the Jewish exiles. But this is a temporary subversion. Esther allows herself to be the object of masculine desire. This gives her power, but that power is limited: there is a doubled discourse in which female sexuality can both subvert social order, while at the same time reinforcing the dominant system. Esther ultimately conforms to this system by bending to the requirements of the male gaze.

This doubled discourse is reflected in the reception history of the book. While Esther is celebrated in the book that bears her name-and certainly her actions benefitted Israel—clearly there are elements to that book which its readers felt uncomfortable with. In the Hebrew book of Esther, Esther does not seem to follow the Jewish dietary laws. This seems to have particularly troubled the translator of the Old Greek of Esther, who adds LXX Esth. 14:17 in order to explicitly state that Esther avoided non-koshered food. ${ }^{44}$ Crucially, in the so-called Alpha Text of Esther in the Greek, Esther's beauty treatment is entirely eliminated. While feminine and sexual charms gave Esther a modicum of power in the Hebrew tale that bares her name, later readers and interpreters were uncomfortable with this explicit utilisation of sexuality. In the Additions to Esther, Addition C has Esther abandon her cosmetics, instead 'every part that she loved to adorn she covered with her tangled hair' $(14: 2)$. In this story it is prayer to God, rather than the

43 This is a 'law for women' (v. 12), required by men 'and not a law prescribed by women for themselves': K. De Troyer, 'An Oriental Beauty Parlour: An Analysis of Esther 2:8-18 in the Hebrew, the Septuagint and the Second Greek Text', in A. Brenner (ed.), A Feminist Companion to Esther, Judith and Susanna (Sheffield: Sheffield Academic, 1995), p. 52.

44 This is also the case in rabbinic literature: L.L. Bronner, 'Esther Revisited: An Aggadic Approach', in A. Brenner (ed.), A Feminist Companion to Esther, Judith and Susanna (Sheffield: Sheffield Academic, 1995), pp. 176-198. 
seductive activities of Esther, which saves the Jews. Cosmetics and sexual charm communicated a persona far too close to the Strange Woman feared in biblical discourse. By adopting the guise of seductress, Esther saved the day, but at the same time made herself a troubling character, and thus her final position must be a troubled one. Ultimately Addition C finds Esther in an untenable situation: sharing a bed with an 'uncircumcised alien' whom she abhors (14:15). Esther is not allowed to enjoy sexual activity or her high status as queen in a foreign court. The modicum of power afforded to Esther in the Hebrew text through the enhancement of her beauty is removed: sexual power is a dangerous one.

\section{The Book of Ruth}

The book of Ruth tells the story of an Israelite woman named Naomi who sojourned in the foreign land of Moab, before she was bereaved of her husband and three sons in quick succession. Ruth is her daughter-in-law, a Moabitess who refuses to abandon her mother-in-law and returns with her to Bethlehem. She is thus a socially liminal figure, a foreigner in a new and strange community undefined by a husband or (male) child who might otherwise integrate her within the social boundaries of her new homeland. In order to support Naomi and herself, she takes to gleaning in the field of a distant kinsman of Naomi, Boaz. According to the obligations of Levirate marriage (Deut. 25:5-10), the brother of a man who dies childless is required to marry the widow of the deceased, with the first-born child named for and treated as the son of the dead man. If either party is unwilling to go through with the marriage, a symbolic act of renunciation of the obligation is required, in which the widow removes the sandal of the living brother and spits in his face. If no living brother is available to marry the widow, as is the case in the story of Ruth, a kinsman of the family might stand in (see e.g. Genesis 38, when the father-in-law of Tamar fulfils this obligation, albeit unwittingly). In the book of Ruth, Boaz is set up as a figure through which the Levirate obligation might be fulfilled. Following an interaction between Boaz and Ruth, Boaz agrees to marry her, although there is a closer kinsmen available: Boaz thus arranges for this 
next-of-kin to renounce his rights to Ruth and give to her his sandal, and marries her himself. The story ends with the birth of their son, and a genealogy connecting Ruth to King David. ${ }^{45}$

The book of Ruth, then, is a story of reversals: the reversal of Ruth from a foreign, liminal figure to an Israelite from whom King David will ultimately be born. This is explicit in the terms used to describe Ruth at certain points in the narrative. Initially Ruth is a נכריה, 'foreign woman' (2:10). Though this is literally the case with Ruth, as a woman from Moab, it also conjures up that other נכריה of the book of Proverbs, the Strange Woman who embodies otherness. Following her interaction with Boaz, Boaz describes her as an אשת חיל, 'worthy woman' (3:11), again using the language of Proverbs, but this time for the idealised wife (Prov. 31:10-31). In the course of their interaction, Ruth has traversed the binary categories of female figuration in the Hebrew Bible, from strange to worthy, outsider to insider. Key here is the interaction between Boaz and Ruth in chapter 3. Naomi instructs Ruth to wash and oil herself, to dress in a certain garment, and to visit Boaz at night on the threshing room floor where he sleeps. Here Ruth is to uncover Boaz's legs and lay at his feet to await instruction. Apparently Boaz will know what to do. It is these actions which have led commentators such as Lacocque, recalled in the introduction, to couch this as a seduction: like Esther, Ruth has utilised cosmetic oil and fashionable dress to 'allure' Boaz,

${ }^{45}$ Most scholars do not understand the book of Ruth to be a historical witness to the ancestry of David; instead the book is usually taken to be a response to the endogmatic marriage legislation of Ezra-Nehemiah (Ezra 9:10-17; Neh. 13:23-27), and hence dated to the early post-exilic period. See e.g. M.C.A. Korpel, The Structure of the Book of Ruth (Assen: Koninklijke van Gorcum, 2001), pp. 320-233; and Y. Zakovitch, Das Buch Ruth: Ein jüdischer Kommentar (Stuttgart: Verlag Katholisches Bibelwerk, 1999), pp. 38-41,62-64. Whatever one concludes about the cogency of this suggestion, the once-upon-a-time quality of the narrative is suggested by the opening lines, 'In the days when the Judges ruled...'. 
utilizing 'the most controversial resources' of her femininity. ${ }^{46}$ In this case, the narrative sees Ruth the literal strange woman dress up as a figurative Strange Woman in order to communicate her sexual availability to Boaz. He reads these signals and is seduced, thus affecting Ruth's change from strange to worthy, and the fortunes of herself and Naomi from poor to favourable. This has led to diverse interpretations of the specifics of the interaction between the two: Ruth's uncovering of Boaz's legs is taken as a euphemism for genitalia,47 and Ruth's request that Boaz spread his cloak over her (3:9) required as Ruth had apparently disrobed (although nowhere is this stated in the text). ${ }^{48}$ Even the location of the meeting in the threshing room, though we might expect this location given the narrative context of gleaning and agricultural harvest, has been taken to connote a heady sexual implication. 49

Yet close attention to the narrative does not support this particular reading.50 While Esther's use of cosmetics enhanced a face that was already described as attractive (Esth. 2:7), nowhere in the story is Ruth said to be beautiful. Rather than utilising cosmetic preparations in

${ }^{46}$ Lacocque, The Feminine Unconventional, p. 2. See also e.g. L.R. Klein, From Deborah to Esther: Sexual Politics in the Hebrew Bible (Minneapolis: Fortress, 2003), p. 4, who describes Ruth's actions as 'sexual manipulation'.

${ }^{47}$ See e.g. J.M. Sasson, Ruth: A New Translation with a Philological Commentary and a FormalistFolklorist Interpretation (Sheffield: Sheffield Academic, 2nd edn, 1995), p. 67; and P. Trible, 'Ruth in the Hebrew Bible', in C. Meyers (ed.), Women in Scripture: A Dictionary of Named and Unnamed Women in the Hebrew Bible, the Apocryphal/Deuterocanonical Books, and the New Testament (Grand Rapids: Eerdmans, 2000), p. 147.

48 So E. van Wolde, Ruth and Naomi (London: SCM, 1997), p. 70.

${ }^{49}$ See e.g. T. Linafelt and T.K. Beal, Ruth and Esther (Collegeville: The Liturgical Press, 1999), p. 48.

${ }^{50}$ Certainly the sages do not understand Ruth's actions to have entailed seduction - far from her seductive charms, it was her modest behaviour that attracted Boaz (Ruth R. 4.6; Šab. 113b)! 
order to aid the sexual entrapment of Boaz, arguably something else is going on. Ruth is told by Naomi to 'bathe, oil yourself, and put on your garment' (ורכצת וסכת ושמת שפלת); 3:3). The application of perfumed oil was certainly utilised for purposes of beautification, but it was also part of the normal ablutions of both men and women (e.g. Deut. 28:40; Mic. 6:15; 2 Sam. 12:20; 2 Chron. 28:15). On the other hand, Ruth had been recently widowed, and abstention from washing and oiling was a part of the mourning process (2 Sam. 14:1). שמלה, translated here as 'garment', is often taken to mean a special kind of dressy outfit in Ruth 3:3, dictated by the interpretation of Ruth's actions as a seduction. Thus the NRSV translates 'your best clothes'; the NKJV 'your best שמלה שarment', and so on. Yet nowhere else in the Hebrew Bible is this particular association of found. In fact, in 2 Sam. 12:20 David ends his period of mourning by washing, oiling, and changing into his שמלה, his garment, the exact item of clothing worn by Ruth in her visit to Boaz. Accordingly, rather than part of a beautification regime, by bathing, oiling and donning her שמלה Ruth is communicating that her mourning period has ended and hence her availability for marriage. As we have seen, adorning is a symbolic action, one which can indeed encode sexual availability. But in the book of Ruth it is not a brief sexual tryst which Ruth is expressing her openness for, but marriage itself. ${ }^{11}$ Seduction and entrapment was not the aim. Ruth utilised dress and cosmetics to affect a change in the perception of her from widow to potential bride, and Boaz responded accordingly as her kinsmen under the obligation of levirate marriage - by proposing.

This understanding helps elucidate some of the actions of Ruth and Boaz during their latenight tryst. Certainly, רגל, 'foot', can be utilised in the Hebrew Bible as a euphemism for sexual

\footnotetext{
${ }^{51}$ Several other scholars have seen in Ruth's actions the preparations of a potential bride (see e.g. Ezek. 16:8-12; Isa. 61:10; Jer. 2:32), without understanding the implication of washing, oiling and dressing as a symbolic end to the mourning process. See e.g. E. Zenger, Das Buch Ruth (ZBAT, 8; Zürich: Theologischer, 1986), pp. 66-67; Sasson, Ruth, pp. 66-67; and V.H. Matthews, Judges and Ruth (NCBC; Cambridge: CUP, 2004), p. 233.
} 
organs. ${ }^{52}$ But this is not the word provided in the narrative of Ruth: instead מרגלית (something like 'the place of the feet') is the precise lexeme employed, found only here in the book of Ruth and at Dan. 10:6, where it is employed in parallel to זרוע, 'arm', hence 'leg' rather than 'foot' seems to be the implication. Perhaps the scribe has avoided the more conventional to recall sexual organs, in place of an alternative lexeme in order to avoid any sexual implication. Instead, Ruth, who is demonstrating to Boaz her availability for marriage through her apparel, could accordingly be understood to uncover Boaz's feet in order to remind him of the levirate obligation, where the removal of the sandal signifies the termination of the obligation. Ruth is marriageable, and Boaz as her kinsmen obligated to marry her. This is explicit in the first words which Ruth speaks to Boaz during their encounter: גאל אתה, 'you are next-of-kin' (3:9). By removing his footwear, Ruth is recalling the Levirate law; by bathing and oiling herself and donning her שמלה, Ruth is demonstrating her availability to fulfil this law. Consequently, Ruth is able to affect a change in her status from unmarried outsider to the wife of an Israelite, and an אישת חיל at that.

\section{Conclusions}

I began by noting a common trend in the scholarly reception of the stories of Esther and Ruth to read the actions of each in parallel, as the utilisation of feminine sexuality in order to affect God's will. Certainly each utilises cosmetic oil at key points in the narratives that bear their names. The popularity of the use of cosmetics in ancient Palestine was affirmed by a study of the archaeological evidence for cosmetic use, encompassing tools for the application of cosmetics, as well as storage containers for powders, creams and oils, perfume bottles, and polished mirrors yet our textual evidence for cosmetic usage in the Hebrew Bible was few and far between. When cosmetics are mentioned, this is usually in the context of sexual impropriety, and consequently

52 BDB, p. 920. 
condemned. This is consistent with the characterisation of the Strange Woman in certain biblical texts, and the threat of her sexual allure and beauty. Her counterpart, Woman Wisdom, the ideal wife, would never partake in the use of cosmetics in order to increase her beauty and express her sexuality.

Yet in contrast to this common biblical image, Esther and Ruth are not condemned for their actions. This suggested exploring the role of cosmetics in these two texts. Utilising a sociological approach, it was demonstrated that cosmetic adornment is a key means by which a wearer can convey something specific about their social or sexual status. Consequently, it was argued that the use of cosmetics by these two biblical characters was the symbolic means by which certain desires and intentions were communicated by Esther and Ruth, and read by those around them. Close textual study demonstrated that, despite the prevalent scholarly view, the function of cosmetic oils in these two tales fundamentally differed. Esther indeed utilised cosmetics to enhance her sexuality, in order to win favourable treatment from the Persian king; yet because this entailed essentially adopting the persona of the Strange Woman, later interpreters of the book began to feel uncomfortable with Esther's actions, and the description of her cosmetic treatments was consequently revised from the story - it is God, rather than Esther, who is the hero of the Greek versions of this tale. On the other hand, and against the scholarly consensus that read the character as a seductress, Ruth utilised cosmetic oil not to ensnare Boaz in a sexual trap, but rather to communicate her marriageability and hence to remind him of his legal obligations to her under the tenets of the Levirate law. In so doing, she is able to move away from the image of the Strange Woman, to become a worthy wife. Understanding the sociological function of cosmetics has provided a new access into the fundamentally differing role of cosmetics in these two biblical books, illuminating difficulties within the narrative contours of the tales as well as their treatment in the hands of later interpreters. 